\title{
REVIEW
}

\section{Germ Warfare}

\section{Karin Knorr-Cetina}

Bruno Latour, Les Microbes: guerre et paix suivi de Irréductions (Paris: Editions A.-M. Métailié, 1984), 281pp., 90 Ffr. ISBN 286424-30-0.

Bruno Latour's book on The Microbes: War and Peace followed by his Irreductions is, I am pleased to say, one of the few studies in our field which, by the very generality of its claims, is likely to evoke a combative response from even the most unresponsive reader. In other words, the book lays itself open to critique, a pleasure rarely offered these days by the more cautiously formulated, hedgedaround assertions found in comparable publications. Consider the layout of the volume, which really contains two books in one. The first presents a historical study of the joint transformation of bacteriology and French society between 1870 and 1914, through the work of Pasteur and his followers. The second 'book in the book' is a small philosophical treatise written in the style of the later Wittgenstein's Philosophical Investigations, in which Latour attempts to replace various reductionisms in our conception of science, society and nature by his own 'irreductions'. The format of this treatise is Latour's first unorthodoxy and a daring endeavour who can stand the comparison with Wittgenstein suggested by Latour's style and emerge unruffled and perhaps even lauded? But this is merely a matter of the form of presentation. What about the content of the two parts? Does it live up to the philosophical ambitions implied by Latour's choice of style? I think it does. The treatise contains a general (not just 'sociological') theory and some methodological corollaries regarding how an agent (Latour uses

Social Studies of Science (SAGE, London, Beverly Hills and New Delhi), Vol. 15 (1985), 577-85 
Greimas' term 'actant'), in war and peace, in science and society, becomes 'great'. The historical study of Pasteur contains an empirical illustration and instantiation of the theses assembled in the treatise. Let me briefly summarize the content of this illustration.

The basic question Latour sets out to answer in his historical investigation is how we can explain the transformation of living conditions and the 'revolution' of the medical sciences in Europe at the turn of the twentieth century. According to Latour, the common reply to this question among contemporaries and historians of science has been: 'Pasteur'. To be sure, most scholars would admit that Pasteur cannot singlehandedly have brought about these transformations. Yet Latour finds that they maintain that Pasteur had, in a nutshell, provided all the concepts and ideas which triggered the revolution. In order to question this claim about Pasteur, Latour uses Tolstoy's argument in War and Peace regarding the relative importance of 'great men' in directing an army and deciding a battle. The force of one person, however strong, is not enough to win a battle; multitudes of forces, including those of allies and soldiers, are necessary to achieve such a goal. But doesn't the power of a person reside in the control he or she exerts over these multitudes of forces? Tolstoy's answer is 'no'. No one human being can control the multitudes of forces that are activated in a battle; no one-dimensional scheme of explanation that attributes causal efficacy solely to one participant can account for the many accidents and idiosyncracies that contribute to its outcome. Similarly, Latour argues, if Pasteur is perceived as a monolithic moving force, that is because the work of unknown masses has been attributed to him.

The masses 'behind' Pasteur which Latour considers to have contributed a large share to this work are the hygienists. The hygienist movement existed long before Pasteur appeared on the scene. Yet before Pasteur, its struggle against infectious diseases was hampered by the fact that it lacked a handle on the variability, diversity and frequency with which the diseases occurred. Statistical analysis alone (which the hygienists employed skilfully and diligently) could not explain variability and frequency. And hygienic measures that affected everything and nothing could not control the outbreak of diseases. Pasteur provided the handle the hygienists needed: a clear-cut localization of the enemy (the microbe) and a weapon (vaccines) by which one could attack it directly without deviation or detour. The hygienists used Pasteur as one would use a military outpost in a battle (p. 41): as a spy who reported on the 
composition and whereabouts of the enemy so that one knew whom and when to attack. In return for his services the hygienists gave Pasteur their full (and, in the beginning, evidentially unwarranted) public support. According to Latour, the bargain struck between Pasteur and the hygienists was effected by an interest translation. Pasteur's microbes gave credit to the previous hygienic movement and promised to extend its impact and relevance to an almost unlimited degree (perhaps all diseases could be eliminated by appropriate measures). On the other hand, the hygienists' support offered Pasteur the public recognition which was needed for the continued financing and expansion of his work. ${ }^{1}$

To illustrate Latour's contentions by a second example, consider his response to the question of why Pasteur (in contrast to the hygienists) 'won over' certain surgeons, but not the medical profession in general. Because, says Latour, for the surgeons, Pasteur opened up a whole new territory of work in internal medicine, made possible and effective by disinfectants and antiseptic procedures. Family physicians, on the other hand, felt threatened by Pasteur. Apparently, it looked for a while as if he might put them out of work altogether by replacing curative medicine with preventive medicine, with the help of serotherapy. Hence, no persuasive translation of interests was possible between Pasteur and general practitioners until much later in the development, when it turned out that there were, in fact, enough diseases left for practitioners to handle, and that serotherapy could be administered by them.

But besides these interest translations, which resulted in seemingly unprecedented attributions of 'greatness' and 'genius' to Pasteur (what Latour calls the second 'dispositif'), there is another ingredient in Pasteur's success. Latour considers this to be Pasteur's use of the scientific laboratory as his base of support. Pasteur led the enemy (the microbes) to where he was strongest: in the scientific laboratory, natural phenomena can be 'translated' so as to become controllable 'at all times' (pp. 82-83). This is not the achievement of one person's mind or of an innovative idea, but of the constellation of simplifying production mechanisms that constitute a laboratory. For example, in the laboratory, phenomena can be reduced in scale, their effects can be multiplied, their development and life cycle accelerated. This emphasis on the 'material' nature and efficacy of the laboratory, like some of Latour's other claims, agrees well with the results of recent laboratory studies. ${ }^{2}$

Pasteur, apparently, not only employed the laboratory as a tool to 
besiege the enemy (the microbes); he also took the laboratory to the site of diseases (the farm, distilleries, later the colonies), to study the enemy's behaviour on the spot and in person. In a second step, he had the results brought back to his 'central' laboratory, where events could be better controlled to gain certainty regarding the effects studied. A third step routinely employed by Pasteur and his helpers consisted in transforming an area of practice according to laboratory specifications, thus taking care in person of the applicability of results. Canguilhem, in his book on ideology and rationality in the history of the life sciences, described the use of the laboratory as a place 'for dislocating natural events'. ${ }^{3}$ Latour describes, in addition, how Pasteur dislocated the laboratory to control, not only the input, but also the output (the applicability) of his central laboratory operations.

There are other aspects of Pasteur's success strategy which Latour points out, such as his moves, over a lifetime, from one area of work to another, with the new area more important with respect to the number and weight of the groups who had an interest in it, and thus always offering new potential 'recruits' whom Pasteur could 'enroll' to expand his power. But the general thrust of the argument is clear. What explains the phenomenon of 'Pasteur' is not the genius of a man, but the fact that he strove to be used by others for their own purposes, in order to enhance his power and the glamour of his reputation. Second, what explains 'Pasteur' is his skilled use of a technical device (the laboratory) to reverse the power relations between himself and the phenomena under investigation.

In part II of the book, his 'Irreductions', Latour extends and elaborates his notions in philosophical form. Many of the contentions Latour offers us in this treatise correspond to accepted beliefs, not only in recent studies of scientific practice, but also in microsociology in general, particularly in symbolic interactionism and ethnomethodology. For example, Latour asserts that there are no 'real' (objective) equivalences in social reality, only negotiated bargains which set things equal for a time. He contends that all 'reductions' to an equivalence, but also to a distinction such as that between the social and the scientific, result from participants' work, and by implication should be studied with a view to the processes which contribute to their existence. With respect to science, Latour argues against the kind of reductionism that attributes causal efficacy to 'ideas' and that considers reality as the mere outgrowth and application of conceptual innovation. He notes that an assertion 
does not catch on because it is true, but that it is held to be true because it catches on (p. 207). Along the same lines, he emphasizes that 'the real world out there is a consequence of stable power relations and not the cause of their stabilization' (p. 256).

But the 'Irreductions' also contain a formulation of Latour's Nietzschean theory of the political nature of all social life, and this is where he parts company with other microsociological and science studies perspectives. Some forces (agents), he says, want to be stronger than others, want to 'measure' others instead of being measured by them, want to 'translate' instead of being translated ( $p$. 187). How does one agent get stronger than another, given that each constitutes for him/herself a complete and incommensurable world? Latour claims that this occurs by the sole mechanism of 'alignment' of forces - or, phrased differently, by 'enrolling' other forces (agents) for one's own purposes. Enrolment is always asymmetrical, in the sense that it is more profitable to the agent who defines the exchange than to the one who declares him/herself to be 'equally' served. In other words, the one who scores in the end is the one who determines the measuring stick in terms of which equivalences are fabricated between agents. Recall the alignment between Pasteur and the hygienists which allowed Pasteur to become a 'century' ('the century of Pasteur'), and to have a street in every town in France named after him. Science, Latour says, is politics conducted by other means (with microbes, with literary inscriptions).

In the beginning I said that this book was likely to elicit heated response from even the most sympathetic reader, and I can now say why. To argue, as Latour appears to, that much (all?) of social and scientific life can be explained in terms of the alignment of forces provoked by the desire for power of some participants in a general political struggle and brought about with the help of fabricated equivalences (interest translations) is to make a bold claim. Moreover, it is a claim which comes at a time when many students of science and social reality, upon immersing themselves in the detailed study of the everyday processes that constitute these domains, have become increasingly disenchanted with grand explanatory schemes. ${ }^{4}$ My major criticism of Latour's scheme is that it appears to be boldly reductionist, and hence runs against his pronounced goal to develop a non-reductionist analysis of science. Throughout the book, Latour appears curiously unreflective in this matter, and never seems to notice that his reduction of social and scientific life to a particular form of political power struggle which rests upon 
alignment and translations does not escape the criticism he advances against other versions of reductionism. How can we avoid such reductionism in our study of the social world as long as we remain interested in general explanations rather than in the 'in vivo' dissection (without subsequent integration) of social reality?

But what is the reductionism Latour attacks? Do we hear him voice a concern similar to the ethnomethodologists' preoccupation with the irremediably coherent and rational-making properties of scientific and everyday accounts? I think not. Rather, Latour castigates the sort of theoretical attitude which tends selectively to perceive and interpret the world in terms of a single set of assumptions, thereby reducing it to a one-dimensional phenomenon. As an astronomer, he says, one tries to derive the evolution of the universe from a single event, the Big Bang. As a mathematician, one searches for a set of axioms which contain all of mathematics in the form of corollaries and consequences. As an intellectual, one traces the simple opinions of everyday life back to the life of ideas. As a follower of Roland Barthes, one thinks the world is composed of nothing but texts and signifiers. And as a male, one is not reluctant to speak of 'men' when one means all of humankind (pp. 181-82). Yes, and as Bruno Latour, the critic might add, one reduces the world to the stratagems of participants conceived of as self-contained, monadic entities, and to the mechanism of affiliation.

Is this a reductionist interpretation of Latour's intentions? Consider his analysis of bacteriology, from which Pasteur emerges as an accomplished political strategist and beneficiary of the alliances he brings about in and through his work and his translations. Throughout this analysis, Latour refers to Tolstoy's attack on the belief that great historical events are made by great human beings with extraordinary powers. In his famous depiction of the battle of Borodino, Tolstoy described the innumerable accidents, misunderstandings, ignored orders, communication breakdowns, spontaneous inexplicable behaviours and unforeseen effects that constituted the course of events and accounted for the outcome of the battle. More generally speaking, Tolstoy pointed out the local, accidental and circumstantial origin of historical events, and the role played by attribution in rendering these events coherent and accountable in terms of single contributing agents or forces.

Latour adopts Tolstoy's criticism of the idea that important historical events are brought about by influential human beings in 
and of themselves. But he ignores Tolstoy's point about the 'lowly' (Nietzsche) origin of historical events in innumerable small and 'chancy' features of the situation. Where, in Latour's account of Pasteur's success, is the reference to the accidents, mistakes, breakdowns, circumstantial factors and disinterested ${ }^{5}$ attributions which presumably helped in the constitution of the phenomenon 'Pasteur', and which occurred perhaps against the will of contributing agents? But perhaps Pasteur's is a special case: one of the few in history in which the production of a new reality (the transformation of French society and medicine) is best understood in terms of the skilled employment of stratagems by a major participant? If so, Latour's references to Tolstoy's War and Peace are as misplaced as is his account of Pasteur's success, to illustrate an irreductionist programme. Both in his empirical illustration and in his philosophical 'precis', Latour advances a monolithic interpretation of the world whose defining characteristics - the political struggles for power through affiliation - miss the point of Tolstoy's subtle criticisms of historical reconstructions.

There are two other points I want to raise. First, the thrust of an argument according to which power ('greatness') is achieved by recruiting others for one's purposes with the help of interest translations, rests upon demonstrating under what conditions these translations of interest will be successful in persuading a potential recruit to become one's ally. Latour's answer to this question in the case of Pasteur and his contemporaries is that the translations were successful when they met the interests of potential coalition partners (as with the hygienists); on the other hand, they were unsuccessful if and when the interests of the two parties involved could not be 'combined' (successfully translated, as with physicians). But to say that a translation of interests is successful if and when it suits the interests of participants is a tautology: one does not explain the success of one protagonist in persuading another of his or her interests by merely repeating the premises of the explanation namely, that it must have been in the interest of the other successfully to conclude negotiations. Perhaps, of course, success in winning over allies is a historically contingent phenomenon inherently unsusceptible to general explanation. But Latour appears to want to give such a general account of successful translation without, however, guarding against the difficulties inherent in interests explanations. ${ }^{6}$

My second point concerns the relevance of Latour's book to the 
sociologist of knowledge. Those committed to the sociology of knowledge perspective must be disappointed by the fact that a major participant in the events, Pasteur's microbes, are not analyzed by Latour. The microbes appear in the book as a weapon in the political struggles between Pasteur and the others, and as newly recognized inhabitants of the social world. But they are treated as if they were natural agents and not - as recent laboratory studies might argue (social) constructions. Thus, in a curious sense, Latour's book stays clear of the 'content' of science, though it does address the question of how politics is made with the help of, and by means of, scientific knowledge. What Latour has to say about the laboratory as a tool to simplify and control natural phenomena does not change the picture. Surely, reference to the availability of such 'tools' is not enough to explain, from a sociology of knowledge perspective, the advent on the scene, and the internal make-up, of microbes. Latour's analysis in this respect is similar to that he and Steve Woolgar favoured in the relevant part of Laboratory Life (Chapter 3). There, Latour and Woolgar defined the construction of a scientific fact to refer to "how, where and why it was created' ${ }^{7}$ meaning by what political stratagems (how and why) Guillemin arrived, at a certain point in time in California (where), at clarifying THE structure of the substance TRF. TRF itself remained unanalyzed, other than in terms of the strategic manoeuvres with the help of which Guillemin succeeded in being first to demonstrate ITS structure. Thus, Latour's book on Pasteur confirms a suspicion I have had for some time now, occasional formulations of Latour which suggest the contrary notwithstanding: Latour is simply not interested in what Donald Campbell and Sal Restivo have called an 'internalist, epistemologically relevant sociology of science'. This, of course, cannot be held against the book. In fact, given the esoteric nature of the questions that preoccupy sociologists of scientific knowledge, it may be an advantage rather than a disadvantage.

I have accused Latour of giving us a Macchiavellian reconstruction of history that emphasizes the production of events by political mastermind strategists at the cost of explanatory tautology, and of neglecting the unplanned and unwanted, strategically accidental outcomes of social action. However, despite this criticism (best epitomized by Latour' $s$ and my distinctively different readings of Tolstoy ${ }^{8}$ ), I want to emphasize that Latour's book has much to offer, both by the fresh approach it takes to the historical study of Pasteur, and by its wider relevance to social studies of science. The historian 
of science will be interested to know that Latour has chosen as his database exclusively scientific journals: he has analyzed fifty years of the Revue scientifique (presumably 1870-1920), thirty years of the Annales de l'Institut Pasteur (founded in 1887), and all explicit allusions to Pasteurism in the Concours médical (1855-1905). His method of analysis relies on coding the articles with a description scheme borrowed from semiotics, though I understand that the details of his procedure, and of some of its results, will be published elsewhere (p. 17). Assuming that historians do not normally rely on such extensive analysis of journals, it should be very interesting to compare Latour's findings with those of contemporary historians of Pasteur (Salomon-Bayet, Geison) who draw upon other sources. Even the non-historian might note, however, that Latour's explanation of the phenomenon of 'Pasteur' in terms of the latter's political alliances, and of attributions, appears infinitely more complex than the 'genius' explanation of 'Pasteur' against which Latour advances his account. Most importantly, perhaps, Latour offers us a social explanation (to become a 'great' person or a macroactor, one must establish and control social relations) that eschews the individualist and mentalist biases inherent in 'genius' theories.

The book has, of course, many other merits, not the least of which is that it is highly readable. Latour has the rare gift of stimulating one's thinking and of giving one ideas, even if one does not agree with what he says! But the greatest interest of the book, and its wider relevance to social studies of science, lies perhaps in the fact that his is the first attempt by a student of scientific practice to begin to analyze the question of the social 'diffusion' of knowledge, of the 'scientization' of society, or of 'knowledge utilization'. These terms are inadequate, and will need to be replaced, but they raise important questions which studies of scientific practice have so far neglected to address. I believe that the whole area of knowledge diffusion and utilization, and of the so-called 'scientization' of society, could profit substantially from a better understanding of scientific practice and, furthermore, from a paradigm shift with regard to the perspectives by which questions of science policy and of knowledge diffusion are addressed. I do not know, of course, whether Latour wishes to bring about such a shift (though I do suspect that, being a 'Pasteurian' in style, he is interested in questions of application!). But who among students of scientific practice would be better equipped - in terms of an interest in 
macroaction and the politics of science - than he to bring about the desirable shift in perspective? Whatever Latour's personal intentions in the Pasteur study may have been, the result can be seen as a first step in such a direction. This, I think, is the true contribution of Latour's book to social studies of science. It is by no means an insubstantial contribution.

- NOTES

1. Readers familiar with Andrew Pickering's work on the adoption of the 'charm' (as opposed to the 'colour') model by the high-energy physics community will recognize the general form of the argument: explanation of scientific choice involves identifying socially acquired and differentially distributed technical competences of specific social groups. See A. Pickering, 'The Role of Interests in High-Energy Physics: The Choice between Charm and Colour', in K. Knorr, R. Krohn and R. Whitley (eds), The Social Process of Scientific Investigation, Sociology of the Sciences Yearbook, Vol. 4 (Dordrecht and Boston, Mass.: Reidel, 1980), 107-38.

2. Besides Latour's own earlier study, B. Latour and S. Woolgar, Laboratory Life: The Social Construction of Scientific Facts (Beverly Hills, Calif.: Sage, 1979), I have in mind S. Traweek, Buying Time and Talking Space: The Culture of the Particle Physics Community (Princeton, NJ: Princeton University Press, forthcoming), M. Lynch, Art and Artifact in Laboratory Science (London: Routledge and Kegan Paul, 1985), and K. Knorr-Cetina, The Manufacture of Knowledge: An Essay on the Constructivist and Contextual Nature of Science (Oxford: Pergamon Press, 1981).

3. G. Canguilhem, Idéologie et rationalité dans l'histoire des sciences de la vie (Paris: Vrin, 1977), 73.

4. Historians of science, of course, have always been unimpressed with the grand explanatory schemes, and have rather preferred to give close attention to the detailed description of historical events. Hence, it would be particularly interesting to hear what historians of science have to say about Latour's account.

5. Unlike the attributions of greatness to Pasteur by the hygienists (which, according to Latour, were motivated by self interest), many attributions in Tolstoy's account appear to made for ad hoc reasons, or for no reasons at all.

6. For a general critique of potential difficulties in interests explanations, see $\mathbf{S}$. Woolgar, 'Interests and Explanations in the Social Study of Science', Social Studies of Science, Vol. 11 (1981), 365-94.

7. Latour and Woolgar, op. cit. note 2, 127.

8. For my reading of Tolstoy, see K. Knorr-Cetina, 'Toward a Reconstruction of Macrosocial Order', paper presented at the Annual Meeting of the American Sociological Association, San Francisco, 1982, forthcoming in Zeitschrift für Soziologie.

\section{Author's address: Faculty of Sociology, University of Bielefeld, PO Box 8640, D-4800 Bielefeld, F. R. Germany.}

